\title{
Journey to Shariah Hospital:An Indonesian Experience
}

Ismail SA ${ }^{1}$, Hamid $B^{2}$, Sulistiadi $W^{3}$, Sagiran ${ }^{4}$

\begin{abstract}
$\underline{\text { Abstract }}$
Objective: As the world's most populous Muslim country, Indonesia carries the responsibilityto establish an Islamic healthcare system that are of superior quality. Believing that Islamic Shariah is the best system for any activity, the need to translate the system into a measurable and objective healthcare quality tools are eminent. In 2015 the Standard of Shariah Hospital Certification were published and in 2016 the National Shariah Council produced a fatwa on the implementation of Shariah Hospital. In 2017, a second version of the Standard were published to be formalized by the National Shariah Council as the awarding body. In this article, the working principles of a hospital practicing the Shariah provisions in Indonesia will be explained. Approach and Value: The concept uses the maqasidic approach in it's structure and refers to the National Hospital Accreditation Commission format. Normative standards are conserved and Shariah values are added in all critical points. Further technical details are produced to ensure proper implementation of the standards, which are divided into Shariah management and Shariah services. Two hospitals were appointed as the pilot project and many more are awaiting it's implementation. As a conclusion it can be said that Shariah Hospital Certification standards provides added value on top of the national hospital accreditation standards. Hospital performance are expected to improve through the implementation of Shariah Hospital Certification by means of establishing quality work culture in hospital staffs through the inculcation of shariahvalues .
\end{abstract}

Kevwords: Shariah compliant hospital; Shariah Hospital Certification; service quality improvement; Shariah hospital standards

International Journal of Human and Health Sciences Vol. 02 No. 02 April'18 Page : 55-64

\section{Introduction}

Mankind are created by God to serve two functions that is to become the servant of God and the vicegerent of God on Earth. Allah ordained in the Quran, "We have not created jin and man except to worship (Allah)" in Surah Adz-Dzariyat verse 56. Thus, every activities in human life is for obedience, submission and devotion. The Islamic shariah is to facilitate the performance of ibadah in all aspects of life. It is also aimed to govern individual and societal affairs in life so as to uphold justice, mercy, wisdom and common good in those affairs, namely ibadah (worship), mu'amalah (dealings with fellow human), munakahah (marriage) and jinayah (criminality) ${ }^{1}$. God sent down the Islamic shariah as guidance for man's life, and it is acceptable and applicable to all mankind. From the aspect of usulfiqh these

1. Dr Siti Aisyah Ismail, MHA: Islamic Health Institution Network of Indonesia (MUKISI), Email: dr.sitiaisyah@gmail.com

2. Dr Burhanuddin Hamid, MHA: Islamic Health Institution Network of Indonesia (MUKISI)

3. Email: burhan1107@gmail.com

4. Dr Wahyu Sulistiadi, MHA, PhD: Hospital Administration Studies, Faculty of Public Health,

5. University of Indonesia, Email: wahyufphui@gmail.com

6. Dr Sagiran, MMed, PhD, Islamic Health Institution Network of Indonesia (MUKISI) Email: gus_sagiran@yahoo.com

Correspondence to: Dr Siti Aisyah Ismail, MHA: Islamic Health Institution Network of Indonesia (MUKISI), Email: dr.sitiaisyah@gmail.com, Premier Terrace No C16,Jalan Raya Ciracas, Ciracas, Jakarta Timur 13740, Indonesia 
purposes are called maqasid as-shari'ah, the purpose and objectives of the Islamic shariah. The scholars defined the purpose of shariah in five aspects: Hifzh Ad-Din (protection of religion), HifzhAn-Nafs (protection of life), Hifzh Al-'Aql (protection of the mind), Hifzh An-Nasl(protection of progeny), and Hifzh Al-Maal (protection of wealth). These five purposes of the Islamic law in literature is called al-maqasid al-khamsah or almaqasid ash-shari'ah'.

The purpose of the shariah is to bring goodness for mankind. MaqasidShari'ah is a concept to understand the hikmah(the shariah values and objectives contains explicitly and implicitly in the Quran and hadith), set by God for mankind. The ultimate goal of the law is to bring maslahah or goodness and benefit for mankind both in this world (through mu'amalah) and the hereafter (by 'aqidah and 'ibadah). In order to gain maslahah,man has to take everything that is beneficial to meet the needs of dharuriyat (primary needs), to complete hajiyat (secondary needs), and tahsiniyat or kamaliyat (tertiary needs). Man has also need to prevent and prohibit mudarat that is useless and harmful to life ${ }^{2}$.

The awareness for the need to practice Islam in all aspects of life has brought many Muslims to realize the importance of following the shariah. This awareness has created the demand for new products and services based on shariah to be introduced into the market.

Healthcare service is one of the most important area in public service. As the world's most populous Muslim country, Indonesia carries the responsibility to establish an Islamic healthcare system that are of superior quality. From the Islamic perspective, medicine is looked into from the physical-medical and psycho-spiritual perspectives. Healthcare service in Islam is holistic, adopting the universal Islamic values. A shariah compliant hospital is an organization which has the scope of work, policies, procedures and staffing requirements that complies to the shariah principle in totality. It does not only focus in halal products or shariah compliant services, nor provide an Islamic alternative within a conventional system. Rather, it is an all-new comprehensive system, formally recognized and certified by an independent body which has the authority to carry out the accreditation process to ensure the organization is following procedures as per shariah requirements.

Believing that Islamic Shariah is the best system for any activity, the need to translate the system into a measurable and objective healthcare quality tools are eminent. In 2015, the Islamic Health Institution Network of Indonesia or, MajelisUpayaKesehatan Islam Seluruh Indonesia

(MUKISI) published a hospital service standard based on Islamic Shariah principles, which complements the National Hospital Accreditation Standards. Two hospitals were made the pilot projects.In 2016 the National Shariah Council of Indonesian Council of Ulama or Dewan Syariah Nasional MajelisUlama Indonesia (DSN-MUI) produced a fatwa on the implementation of Shariah Hospital. In 2017, a second version of the Standard were published to be formalized by the National Shariah Council as the awarding body. This effort was initiated back in 2009 during the national work meeting (RAKERNAS) of MUKISI in Batu Malang, then in SerangBanten on 2012, and in Bandung early 2015.

The process of producing the standard for service and management in shariah hospital underwent a very long and in depth study and discussions between MUKISI and DSN-MUI. The medical aspect of the standard were tackled by MUKISI and the shariah critical control points were addressed by DSN-MUI. The first version of the standard (version 1436H) were implemented to the pilot projects, and after one year, assessments were carried out and revision, improvement, enhancement and refinement were made, thereupon produce the second $1438 \mathrm{H}$ version of the standard.

\section{The Awarding Body}

In Indonesia, the Indonesian Council of Ulama or MajelisUlama Indonesia (MUI) is an independent body representing the Islamic scholars of Indonesia to rectify public issues pertaining to the Islamic law. MUI is an independent non-governmental organization that accommodates Islamic scholars to guide and nurture the Muslims in Indonesia. It was established in 7th Rajab 1395 Hijriyah/26th July 1975 in Jakarta, Indonesia ${ }^{3}$. Among others, the role of MUI are:

1. To provide guidelines to Muslims in Indonesia to practice religious living in a community blessed by Allah.

2. To provide advice and fatwa on religious and societal issues to the government and the public, to promote $u k h u w a h$ Islamiyah

(Islamic brotherhood) and harmony in multireligious community in uniting the nations.

3. To become the liaison between the Islamic 
scholars and the government, and the reciprocal translator for the public and the government in order to achieve national development.

4. To increase cooperation between organizations, Islamic institutions and Islamic scholars in providing guidelines for the public through consultations and reciprocal information Some of the agencies under MUI that are related to healthcare services are:

1. Fatwa Commission or Komisi Fatwa; provide consultation, perform research and produce fatwa related to issues pertaining the Islamic law in general.

2. National Shariah Council or Dewan Syariah Nasional (DSN); provide consultation, perform research and produce fatwa on specific issues related to economy or financial activities.

3. Appraisal Body for Food, Drugs and Cosmetics

OrLembagaPengkajianPanganObatobatandanKosmetika (LPPOM); provide halal consultation and research, set the regulations

and procedures for halal certification, perform halal audit and certification.

In October 2016, DSN-MUI produced fatwa No. 107/DSN-MUI/X/2016 on The Guidelines of Hospital Administration Based on Shariah Principles, which emphasized on four critical elements that must comply with the shariah principles, namely the akad (contracts), services, halal food and drugs, and financial management. The scope and points discussed in the fatwa is summarized in the diagram below.

Then in March 2017, DSN-MUI together with MUKISI produced a second version of the Standard for Shariah Hospital Certification, which was validated by decree No. KEP-13/ DSN-MUI/ III/2017. Together with the book of standards, three other guidelines were published i.e.: minimum

shariah service standard and compulsory shariah quality indicators, shariah hospital ethical code, and physicians ethical code in shariah hospital.

\section{Shariah Compliant Hospital}

A shariah compliant hospital is where healthcare services provided are in accordance with the shariah principles, or simply means implementing the maqasidshariahin the hospital governance. What are the characteristics of a shariah compliant

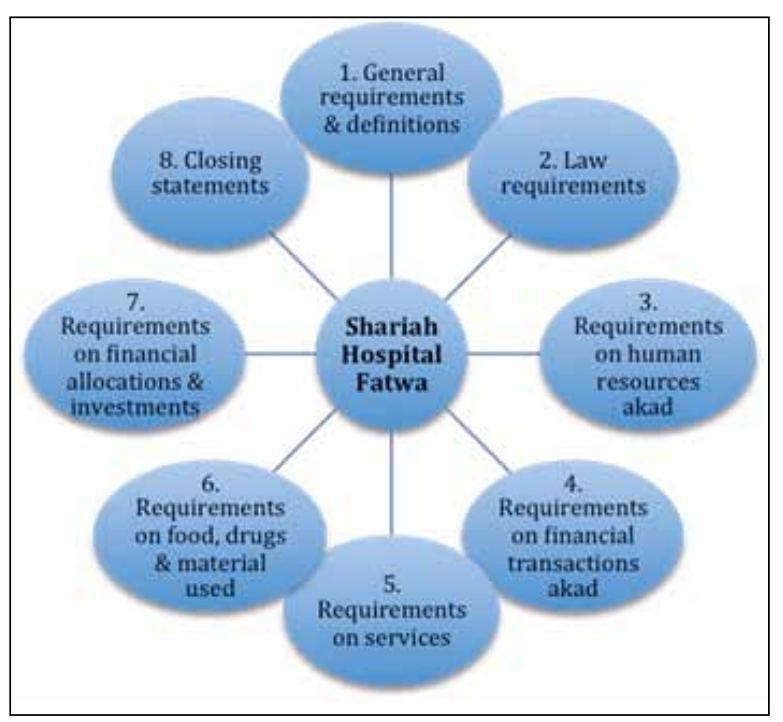

Figure 1. The scope of the Fatwa on Guidelines of Hospital Administration based on Shariah Principles

hospital, that made it different from other hospital? The following are some unique features of a shariah compliant hospital. Implementation of these components will truly reflect Islam as the comprehensive way of life ${ }^{1}$.

1. Understanding the basic principles of shariah

2. Understanding the principles of halal and haram

3. Understanding the principles of mualamat

4. Implementing the concept of quality in Islam

5. Establishing the Islamic core values within the hospital organization

These component is then translated into operational management and services in the book of standard ${ }^{4}$. Some of the characteristics are:

1. Shariah Supervisory Board is appointed to supervise the hospital's operation

2. Hospital By Laws includes shariah aspects

3. The mission and vision of the hospital explicitly states Islamic objectives

4. Conducts shariah contracts (akad) with staffs, patients, logistics suppliers, financial institution and others

5. Management of human resources applies the shariah principles in its practice

6. The accounting and financial management uses shariahprinciples

7. Provides physical means and facilitate the performance of worship to patients, staffs and visitors

8. Provides spiritual guidance for patients and specific spiritual coaching for terminally ill patients

9. Ensures halal, hygienic and safe food and nutritional therapy 
10. Guarantees the effort to cover patient's aurah(private parts), like-gender services andprevention of ikhtilat (free mixing)

11. Infection control and its prevention uses the principle of taharah (cleanliness)

12. Conducts mandatory religious training for all staffs

13. Handles complaint, conflict or difference in International Journal of Human and Health

Sciences Vol. 01 No. 02 April' 17 opinion, in accordance with the shariah

14. Provides Islamic reproductive health service

15. The hospital pays institutional zakat (obligatory alms) which is used to help patients in need

The hospital are managed and the delivery of healthcare services are in accordance with the shariah principles and practices. It upholds the universal values of Islam, the principle of justice, peace, freedom and equality in its daily operation. From the management perspectives, Rezekior livelihood is guaranteed by God. Income cannot be defined only through financial quantification. The owner and the shareholders did not build the hospital with a profit-making paradigm only, but rather how barakah can be felt. The implementation of zakat in the financial management of the hospital has proven to increase its income. The hospital also pays extra attention towards efficiency through the implementation of several policies like Lean management, and fostering values on the concept of preventing mubazir(waste) into the mental model of the staffs. The management sets a shariah policy to establish quality work culture in staffs because staffs are the one who carry out the services in the hospital. Policies implemented by the management are perceived by employees as an effort to establish discipline and good work commitment. A disciplined and committed employee will show good attitude and performance, perceived by patients as the recipient of service ${ }^{5}$.

When patient comes to the hospital, they were treated as though a guest. Hospital service system and the staffs put efforts in delivering the best service. This concept is internalized in all hospital service elements because honoring guest is part of Iman (faith). When staffs realized that the service they provide to patients is a manifestation of their faith in God, they will strive to give their best ${ }^{5}$. Working is an act of worship and provide the chance to perform good deeds. Every aspect of human life is part of ibadah, including work. Staffs are the hospital's biggest and most important asset. When staffs understood that work is not a burden but an ibadah, they will put effort to perform ${ }^{5}$. The hospital provides an avenue for staffs to achieve Islamic fulfillment and obligation in their personal and professional lives devoid of dichotomy and dualism. It is not only a working place but also provides the means for tarbiyah (Islamic training) to the staffs.

Some of the improvement perceived by patient and visitors are from the aspect of staffs attitude, service delivery, physical facility and level of cleanliness in the hospital after the implementation of Shariah Hospital standards. Shariah values implemented such as efficiency, maintenance of patients aurah and privacy, the reminder for salah time, spiritual guidance, security assurance, halal assurance for food and medications are among others that were mentioned as a unique experience in the hospital ${ }^{5}$.

Healing is only from God. This concept is the very foundation of healthcare service in the hospital. When this concept is truly internalized, both patient and the healthcare provider will give their best effort in getting cure, but still aware that it is God who has the right to heal. So whatever the outcome of the effort is, it is accepted obligingly 5 . The spiritual wellbeing is regarded as important as the physical wellbeing. Being sick is an awakening moment, where one needs to take a break from worldly matters, introspect into ones life, realizing that this worldly life is just a timeline to move to another dimension; the eternal hereafter. As much as we prepared for the birth of a baby, the same preparation needs to be done in facing death.

\section{Shariah Hospital Certification}

In the govermance of an organization, compliance has the meaning of following a specification, standard or regulations set by the authority. The specification, standard or regulations can be in the form of policy or work procedure, which when implemented correctly and well, the internal control system will run effectively and prevent the possibility of fraud. The term shariah compliant indicates compliance towards the Islamic shariah law in the governance and operation of the organization ${ }^{6}$.

The shariah compliance concept was developed initially in the banking industry, hence the popular term "Islamic Banking". Eventually develop in other industry like food industry through the halal assurance system, the fashion industry, cosmetics, tourism and others. This development are based on 
high market demand of products with the shariah compliant label or recognition?

Shariah compliance simply means implementing the maqasidshariah in the governance of a system. A standard reference and system is needed to ensure compliance. Thus, the standard of Shariah Hospital Certification is published to provide the reference in the implementation of the

maqasidshariah in healthcare service system in ahospital ${ }^{4}$. The standard of Shariah Hospital Certification consists of five chapters which is a breakdown of the maqasidshariah. Each chapter is divided into two groups; the shariah management standards and the shariah service standards ${ }^{4}$. This will serve as a reference and guidelines for any hospital to be certified as Shariah Hospital in the future. The hospital then needs to translate the operational and work process in the delivery of healthcare services into policies, guidelines and standard operating procedures (SOPs).

The basic format of the standards uses the hospital accreditation standards format by the National Hospital Accreditation Commission or KomisiAkreditasiRumahSakit (KARS). This is to facilitate the management and hospital staffs in implementing the shariah standards in a similar mindset. The nature of the standards are also complementary to that of the KARS

standards. The shariah standard only mentions aspects that contains shariah critical control points as an addition. The normative ones and the ones which do not contain shariah values within their documentation and implementation are not included into the certification standard of shariah hospital. From those standards, the elements of assessment are determined to assess the level of compliance. The element of assessment consists of documents review, patient survey and facility survey which are also in accordance with the assessment methodology by KARS hospital accreditation. Assessors conducting the survey are from DSN-MUI and MUKISI.

The certification standard of shariah hospital consists of five chapters of the maqasidshariah, and each chapters are divided into two standard groups; the shariah management standard group and shariah service standard group. The systematics of the standard of Shariah Hospital Certification are as follows:
Chapter 1. Protection of religion (Hifzh Al-Din):

Chapter 2. Protection of life (Hifzh Al-Nafs):

Chapter 3. Protection of the mind (Hifzh Al-'Aql):

Chapter 4. Protection of progeny (Hifzh Al-Nasl):

Chapter 5. Protection of wealth (Hifzh Al-Mal):
33 standards, 119 elements of assessment 6 standards, 20 elements of assessment

6 standards, 15 elements of assessment

2 standards, 7 elements of assessment

4 standards, 14 elements of assessment 
International Journal of Human and Health Sciences Vol. 02 No. 02 April'18

Table 1.Standards and Assessment Elements of Shariah Hospital Certification Version 1438

\begin{tabular}{|c|c|c|c|c|}
\hline Chapter & $\begin{array}{c}\text { Shariah Management } \\
\text { Standard Group }\end{array}$ & $\begin{array}{l}\text { Elements } \\
\text { of } \\
\text { Assessment }\end{array}$ & $\begin{array}{c}\text { Shariah Service Standard } \\
\text { Group }\end{array}$ & $\begin{array}{l}\text { Elements } \\
\text { of } \\
\text { Assessment }\end{array}$ \\
\hline $\begin{array}{l}\text { Chapter } 1 \\
\text { hifzh al-din }\end{array}$ & $\begin{array}{l}\text { 1. Shariah Standard } \\
\text { on Organizational } \\
\text { Management (SSMO) } \\
\text { 2. Shariah Standard } \\
\text { on Human Capital } \\
\text { Management (SSMMI) } \\
\text { 3. Shariah Standard on } \\
\text { Accounting and Finance } \\
\text { Management (SSMAK) } \\
\text { 4. Shariah Standard on } \\
\text { Marketing Management } \\
\text { (SSMP) } \\
\text { 5. Shariah Standard on } \\
\text { Facility Management } \\
\text { (SSMF) } \\
\text { 6. Shariah Standard on } \\
\text { Quality Management } \\
\text { (SSMM) }\end{array}$ & 8 & $\begin{array}{l}\text { 1. Shariah Standard on } \\
\text { Service access and } \\
\text { continuity (SSAPK) } \\
\text { 2. Shariah Standard on } \\
\text { Patient Assessment } \\
\text { (SSAP) } \\
\text { 3. Shariah Standard on } \\
\text { Patient Service (SSPP) } \\
\text { 4. Shariah Standard on } \\
\text { Shariah Medication } \\
\text { (SSPO) } \\
\text { 5. Shariah Standard on } \\
\text { Spiritual Service and } \\
\text { Guidance (SSPBK) } \\
\text { 6. Shariah Standard on } \\
\text { Patient and Family } \\
\text { Education (SSPPK) }\end{array}$ & $\begin{array}{l}3 \\
19 \\
9 \\
8\end{array}$ \\
\hline $\begin{array}{l}\text { Chapter } 2 \\
\text { hifzh al-nafs }\end{array}$ & $\begin{array}{l}\text { Shariah Standard on Facility } \\
\text { Management (SSMF) }\end{array}$ & 4 & $\begin{array}{l}\text { 1. Shariah Standard on } \\
\text { Infection Control and } \\
\text { Prevention (SSPPI) } \\
\text { 2. Shariah Standard on } \\
\text { Spiritual Service and } \\
\text { Guidance (SSPBK) }\end{array}$ & 14 \\
\hline $\begin{array}{l}\text { Chapter } 3 \\
\text { hifzh al-'aql }\end{array}$ & $\begin{array}{l}\text { Shariah Standard on Human } \\
\text { Capital Management } \\
\text { (SSMMI) }\end{array}$ & 6 & $\begin{array}{l}\text { 1. Shariah Standard on } \\
\text { Patient and Family } \\
\text { Education (SSPPK) }\end{array}$ & 9 \\
\hline $\begin{array}{l}\text { Chapter } 4 \\
\text { hifzh al-nasl }\end{array}$ & - & - & $\begin{array}{lcc}\text { Shariah Standard } & \text { on } \\
\text { Patient Service (SSPP) } & \end{array}$ & 7 \\
\hline \multirow[t]{2}{*}{$\begin{array}{l}\text { Chapter } 5 \\
\text { hifzh al-maal }\end{array}$} & $\begin{array}{l}\text { Shariah Standard on } \\
\text { Accounting and Finance } \\
\text { Management (SSMAK) }\end{array}$ & 12 & $\begin{array}{l}\text { Shariah Standard on } \\
\text { Patient Service (SSPP) }\end{array}$ & 2 \\
\hline & Total & 92 & Total & 83 \\
\hline
\end{tabular}

In the book of standards, the standards and their elements of assessments are presented using alphanumeric code to facilitate the assessment process. The standards and their elements were presented in narrative form in the first part of the book, then presented in table form in the second part of the book. The coding of the Standard of Shariah Hospital Certification, are explained below:
The standard and its key elements are explained briefly in Table 2 and Table 3 below:

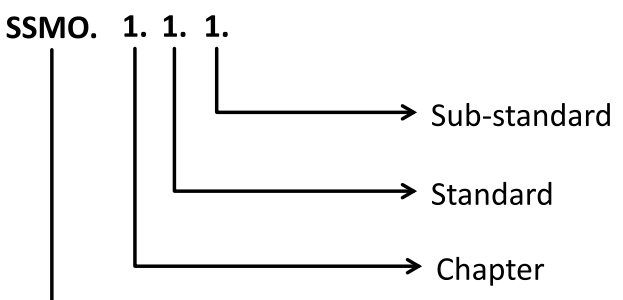

Abbreviation of the standard title 
International Journal of Human and Health Sciences Vol. 02 No. 02 April'18

Table 2. Standard and Key Elements of ShariahManagement Group

SHARIAH MANAGEMENT STANDARD GROUP

\begin{tabular}{|c|c|c|}
\hline Chapter & Standard & Key Elements \\
\hline \multirow{17}{*}{$\begin{array}{c}\text { PROTECTION } \\
\text { OF RELIGION } \\
\text { (HIFZH AD- } \\
\text { DIN) }\end{array}$} & \multirow{9}{*}{$\begin{array}{l}\text { Shariah Standard on } \\
\text { Organization Management } \\
\text { (SSMO) }\end{array}$} & $\begin{array}{l}\text { Responsibility and accountability of the hospital owner can be } \\
\text { certified by the completeness of document }\end{array}$ \\
\hline & & $\begin{array}{l}\text { Shariah Supervisory Board (DPS) is appointed by the owner to supervise the } \\
\text { hospital operation }\end{array}$ \\
\hline & & Hospital By Laws which includes shariahaspects are stipulated by owner \\
\hline & & Hospital establishes vision and mission which conveys Islam explicitly \\
\hline & & $\begin{array}{l}\text { The hospital appoints shariah committee to ensure the service operation in the } \\
\text { hospital is conducted based on shariahpriciples }\end{array}$ \\
\hline & & $\begin{array}{l}\text { Hospital administrator appoints institution for mosque caretaker (takmir) to } \\
\text { conduct } d a \text { 'wah and run the hospital's mosque/musolla }\end{array}$ \\
\hline & & $\begin{array}{l}\text { Hospital administrator appoints spiritual advisory unit within its organization } \\
\text { and governance }\end{array}$ \\
\hline & & The hospital establishes guidance on shariah hospital ethics \\
\hline & & The hospital conducts shariah contract ( $\mathrm{Akad}$ ) \\
\hline & \multirow{4}{*}{ Shariah Standard } & $\begin{array}{l}\text { The hospital has shariah human capital management in their } \\
\text { recruitment process, competency development and career management }\end{array}$ \\
\hline & & $\begin{array}{l}\text { The hospital has shariah human capital management in the determination of } \\
\text { the key performance indicators (KPI), performance assessment, and reward } \\
\text { and punishment system }\end{array}$ \\
\hline & & $\begin{array}{l}\text { The hospital has a guidelines in the implementation of general and specific } \\
\text { hospital orientation activities that contains Islamic values }\end{array}$ \\
\hline & & The hospital applies the shariah hospital doctor's ethical code \\
\hline & $\begin{array}{l}\text { Shariah Standard on } \\
\text { Accounting and Finance } \\
\text { Management (SSMAK) } \\
\end{array}$ & The hospital has shariah accounting and finance management \\
\hline & $\begin{array}{l}\text { Shariah Standard on } \\
\text { Marketing Management } \\
\text { (SSMP) } \\
\end{array}$ & $\begin{array}{l}\text { The hospital has shariah-compliant marketing management The hospital may } \\
\text { promote health services to the public by not violating the principles of shariah }\end{array}$ \\
\hline & $\begin{array}{l}\text { Shariah Standard on } \\
\text { Facility Management } \\
\text { (SSMF) }\end{array}$ & $\begin{array}{l}\text { The hospital takes principles of shariah into account in facility } \\
\text { provision and management }\end{array}$ \\
\hline & $\begin{array}{l}\text { Shariah Standard on } \\
\text { Quality Management } \\
\qquad \text { (SSMM) }\end{array}$ & $\begin{array}{l}\text { The hospital sets policies and guidelines on quality which } \\
\text { includes the maintenance of aqidah, worship, morality and } \\
\text { mu'amalah(financial transaction). }\end{array}$ \\
\hline $\begin{array}{l}\text { PROTECTION } \\
\text { OF LIFE }\end{array}$ & $\begin{array}{c}\text { Shariah Standard on } \\
\text { Facility Management } \\
\text { (SSMF) }\end{array}$ & $\begin{array}{l}\text { Facility and environmental risk management program includes } \\
\text { prayer facility fulfillment and management }\end{array}$ \\
\hline $\begin{array}{l}(H I F Z H A L- \\
\quad N A F S)\end{array}$ & $\begin{array}{l}\text { Shariah Standard on } \\
\text { Infection Control and } \\
\text { Prevention (SSPPI) } \\
\end{array}$ & $\begin{array}{l}\text { The hospital has infection control and prevention program based on } \\
\text { modern science corresponding to applicable law and constitution, } \\
\text { sanitation standard and cleanliness based on shariah principles }\end{array}$ \\
\hline $\begin{array}{c}\text { PROTECTION } \\
\text { OF THE MIND } \\
\text { (HIFZH } A L- \\
\text { 'AQL) }\end{array}$ & $\begin{array}{c}\text { Shariah Standard } \\
\text { on Human Capital } \\
\text { Management (SSMMI) }\end{array}$ & $\begin{array}{l}\text { The hospital determines the policy on staff's competency on the fiqh } \\
\text { (Islamic jurisprudence) of the sick }\end{array}$ \\
\hline $\begin{array}{c}\text { PROTECTION } \\
\text { OF PROGENY } \\
\text { (HIFZH } A L- \\
\text { NASL) } \\
\end{array}$ & - & - \\
\hline $\begin{array}{c}\text { PROTECTION } \\
\text { OF WEALTH } \\
\text { (HIFZH } A L- \\
M A L)\end{array}$ & $\begin{array}{l}\text { Shariah Standard on } \\
\text { Accounting and Finance } \\
\text { Management (SSMAK) }\end{array}$ & $\begin{array}{l}\text { The hospital and/or staffs pay zakat (obligatory alms), infaq and } \\
\text { charity (ZIS) }\end{array}$ \\
\hline
\end{tabular}


International Journal of Human and Health Sciences Vol. 02 No. 02 April'18

Table 3. Standard and Key Elements of Shariah Service Group

SHARIAH SERVICE STANDARD GROUP

\begin{tabular}{|c|c|c|}
\hline Chapter & Standard & Key Elements \\
\hline \multirow{18}{*}{$\begin{array}{l}\text { PROTECTION OF } \\
\text { RELIGION } \\
(\text { HIFZH AD-DIN })\end{array}$} & & Hospital defines the standard of operational procedures \\
\hline & \multirow{2}{*}{$\begin{array}{l}\text { Shariah Standard on Service } \\
\text { Access and Continuity (SSAPK) }\end{array}$} & for patient reception, direction and discharge \\
\hline & & $\begin{array}{l}\text { The hospital complements the transportation standards } \\
\text { with Islamic audio or video media }\end{array}$ \\
\hline & $\begin{array}{c}\text { Shariah Standard on Patient } \\
\text { Assessment (SSAP) }\end{array}$ & $\begin{array}{l}\text { The hospital sets a spiritual assessment for the patient to } \\
\text { obtain the patient's religious data }\end{array}$ \\
\hline & \multirow{7}{*}{$\begin{array}{l}\text { Shariah Standard on Patient } \\
\text { Service (SSPP) }\end{array}$} & The hospital sets policies and procedures on the services \\
\hline & & for high-risk patients terminal illness \\
\hline & & $\begin{array}{l}\text { Hospital ensures the halal, hygiene and safety of the food } \\
\text { and nutritional therapy given to patients }\end{array}$ \\
\hline & & $\begin{array}{l}\text { Hospital guarantees the effort to cover patient's } \\
\text { aurah(private parts), services according to like-gender and } \\
\text { the prevention of } i k h t i l a t \text { (free mixing) element }\end{array}$ \\
\hline & & $\begin{array}{l}\text { Hospital guarantees anesthetic and surgical services is } \\
\text { according to shariah principles }\end{array}$ \\
\hline & & Hospital provides service for the management of \\
\hline & & ruqyahshar'iyah (shariah exorcism). \\
\hline & \multirow{5}{*}{$\begin{array}{c}\text { Shariah Standard on Shariah } \\
\text { Medication }\end{array}$} & $\begin{array}{l}\text { Hospital seeks drug formularies which do not contain } \\
\text { elements of the unlawful (haram) substances. }\end{array}$ \\
\hline & & The hospital complements supporting documents in drug \\
\hline & & delivery to patients by stating Islamic values \\
\hline & & Hospital staff delivers medicine to patients together with \\
\hline & & the delivery of religious messages \\
\hline & \multirow{3}{*}{$\begin{array}{l}\text { Shariah Standard of Service and } \\
\text { Spiritual Guidance (SSPBK) }\end{array}$} & $\begin{array}{l}\text { The hospital provides Islamic spiritual guidance to } \\
\text { patients }\end{array}$ \\
\hline & & $\begin{array}{l}\text { The hospital provides advisory services to patients who } \\
\text { have special requests }\end{array}$ \\
\hline & & $\begin{array}{l}\text { Hospital provides services for end of life care based on } \\
\text { shariah principle }\end{array}$ \\
\hline & $\begin{array}{l}\text { Shariah Standard on Patient and } \\
\text { Family Education (SSPPK) }\end{array}$ & $\begin{array}{l}\text { The hospital educates about family participation in the } \\
\text { healing process of the patient }\end{array}$ \\
\hline \multirow{4}{*}{$\begin{array}{c}\text { PROTECTION OF } \\
\text { LIFE } \\
(H I F Z H A L-N A F S)\end{array}$} & \multirow{4}{*}{$\begin{array}{l}\text { Shariah Standard on Spiritual } \\
\text { Service and Guidance (SSPBK) }\end{array}$} & The hospital provides shariah funeral service \\
\hline & & The hospital provides pain management service \\
\hline & & $\begin{array}{l}\text { The shariah regulation on human tissue waste } \\
\text { management }\end{array}$ \\
\hline & & $\begin{array}{l}\text { The procurement of water source based on shariah } \\
\text { principle }\end{array}$ \\
\hline \multirow{7}{*}{$\begin{array}{l}\text { PROTECTION OF } \\
\text { THE MIND } \\
(H I F Z H A L-' A Q L)\end{array}$} & Shariah Standard on Human & The hospital holds mandatory religious training for all \\
\hline & Capital Management (SSMMI) & staffs \\
\hline & & The hospital provides library with Islamic literatures \\
\hline & \multirow{2}{*}{ Shariah Standard on Patient and } & The handling of complaint, conflict or difference in \\
\hline & & opinion, in accordance with shariah \\
\hline & Family Education (SSPPK) & $\begin{array}{l}\text { Education and training through good communication } \\
\text { helps in maintaining health }\end{array}$ \\
\hline & & Islamic education to the visitors \\
\hline \multirow{3}{*}{$\begin{array}{c}\text { PROTECTION OF } \\
\text { PROGENY } \\
(H I F Z H A L-N A S L)\end{array}$} & \multirow{3}{*}{$\begin{array}{c}\text { Shariah Standard on Patient } \\
\text { Service (SSPP) }\end{array}$} & The hospital providesshariah maternal and infant \\
\hline & & healthcare service \\
\hline & & The hospital provides Islamic reproductive health service \\
\hline \multirow{5}{*}{$\begin{array}{c}\text { PROTECTION OF } \\
\text { WEALTH } \\
(\text { HIFZH } A L-M A L)\end{array}$} & \multirow{4}{*}{$\begin{array}{c}\text { Shariah Standard on Accounting } \\
\text { and Finance Management } \\
\text { (SSMAK) }\end{array}$} & $\begin{array}{l}\text { The hospital in managing cash, financing, and investment } \\
\text { cooperates with shariah financial institution }\end{array}$ \\
\hline & & The hospital has the policy and mechanism to manage \\
\hline & & patient who cannot afford the bill \\
\hline & & The hospital sets operational standard to be aware of \\
\hline & & billing miscalculation \\
\hline
\end{tabular}


From all five chapters in the standard, participating hospital are required to pass over $80 \%$ of chapter 1 as a mandatory passing requirement. An obligatory pre requisite for the Shariah Hospital Certification assessment is that the hospital must pass the hospital accreditation by KARS. This is made compulsory for shariah compliant certified hospital to be of superior quality and to ensure patient safety 4 .

In general, the Shariah Hospital Certification standard combines the principles in hospital accreditation which are; the concept of service quality, quality assurance, quality improvement, and value based medicine, with the shariah principles namely the maqasidshariah, halal assurance, Islamic branding and shariah compliance. The certification provides added value to the hospital. In the conventional healthcare services, value are perceived by monetary unit. But in Islam, the longevity of value extends beyond this wordly life.

\section{Implementation of Shariah Hospital}

\section{Certification Standards}

In 2015, two hospitals were appointed the pilot projects using the version $1436 \mathrm{H}$ standards. Those two hospitals are Sultan Agung Islamic Hospital in Semarang and NurHidayah Hospital in Yogyakarta. Sultan Agung Islamic Hospital is a class B regional referral and teaching hospital, whereas NurHidayah Hospital is a class D district hospital. Both hospitals achieved the "Mumtaz" predicate on their certification assessments. "Mumtaz" is awarded with five crescents, "Jayyidjiddan" presented with four crescents and "Jayyid" is given three crescents. The reason behind the appointment is to prove that the Shariah Hospital Certification is relevant and implementable to both big and small hospital, to both complex and simple work processes. Recently in June 2017, a formal assessment survey were conducted by DSN-MUI and MUKISI to both hospital, using the latest version $1438 \mathrm{H}$ standard. The survey results were brought to a panel meeting by the DSN-MUI to be further evaluated to determine the predicate of the certification. Both RSI Sultan Agung and RS NurHidayah passed the assessment and received the certification in August and September 2017 respectively. Many hospitals have signed up to wait for their turn to be assessed as Shariah Hospital.

The milestone achieved on this journey is impressive. It took six years from 2009 to 2015, to actually materialize the standards for shariah hospital from what at first seemed to be an impossible notion. Then, within two years of the formulation of the standards, through rounds after rounds of studies, meetings and discussions between MUKISI and DSN-MUI, the fatwa for the implementation of shariah hospital was produced, marking the historical moment for Islamic healthcare services in Indonesia. The standards are now officially owned by DSN-MUI as the awarding body. In a few years, the target is to get the recognition and endorsement for the standard from the the Ministry of Religion and the Ministry of Health.

\section{Conclusions}

1. The journey to produce the Shariah Hospital Certification standards went through long, rigorous and in depth study by MUKISI and DSN-MUI, as a reference for shariah compliant hospital management and services.

2. The Shariah Hospital Certification standards provides added value on top of the national hospital accreditation standards.

3. Hospital performance are expected to improve through the implementation of Shariah Hospital Certification by means of establishing quality work culture in hospital staffs through the inculcation of shariah values. 


\section{$\underline{\text { References }}$}

1. Rahman S. Shari'ah Compliant Hospital; From Concept to Reality: A Malaysian Experience. Bangladesh Journal of Medical Science,2016;15(1):1-4.

2. Kasule OH. Toward Shariah Compliant Hospital:Planning, Implementation and Challenges. 2013;Retrieved from http://omarkasule-tib.blogspot. co.id/2014/02/130726p-toward-shariah-compliant. html (accessed on 16 October 2016)

3. MUI. Sejarah MUI. 2016. Retrieved from http:// mui.or.id/id/category/profile-organisasi/sejarah-mui/ (accessed on 26 June 2017)

4. Majelis Upaya Kesehatan Islam Seluruh Indonesia. 2015. Instrumen Sertifikasi Rumah Sakit Shariah versi 1436. Jakarta: MUKISI

5. Ismail SA. Implementasi Sertifikasi Rumah Sakit Syariah terhadap Kinerja Rumah Sakit di Rumah Sakit Islam Sultan Agung. 2017. Depok:
FakultasKesehatan Masyarakat, Universitas Indonesia.

6. Dargahi H. The Implementation of the Shariah Law inMedical Practice: A Balance between Medical Ethics and Patients Rights in Journal of Medical Ethics and History of Medicine. 2011;4(7) Retrieved from http://www. ncbi . nlm . nih . gov/pmc/articles/ PMC3713915 (accessed on 10 September 2016)

7. Samsudin, K. The Concept of Establishing aShariah Supervisory Committee in Malaysian Hospitals in Procedia - Social and Behavioral Sciences.2015;174:1202-1206. Retrieved from http:// ac.els-cdn.com/S1877042815007892/1-s 2 . 0 - S 18 $77042815007892-\mathrm{main} . \mathrm{pdf}$ ? tid=1 dddafda-8e 72-11e 6-ad 07-00000a a b0f6c\&acdnat $=1476053326$ eb38541058aa6d0468851d2271a44442 (accessed on 8 September 2016) 